\title{
Divergent selection on 63-day body weight in the rabbit: response on growth, carcass and muscle traits
}

\author{
Catherine LARZUL ${ }^{\mathrm{a} *}$, Florence GONDRET ${ }^{\mathrm{b}}$, Sylvie COMBES $^{\mathrm{c}}$, \\ Hubert de ROCHAMBEAU ${ }^{\mathrm{a}}$
}

a Station d'amélioration génétique des animaux, Institut national de la recherche agronomique, BP 27, 31326 Castanet-Tolosan, France

b UMR sur le Veau et le Porc, Institut national de la recherche agronomique, 35590 St Gilles, France

${ }^{c}$ Station de recherches cunicoles, Institut national de la recherche agronomique, BP 27 , 31326 Castanet-Tolosan, France

(Received 2 March 2004; accepted 3 September 2004)

\begin{abstract}
The effects of selection for growth rate on weights and qualitative carcass and muscle traits were assessed by comparing two lines selected for live body weight at 63 days of age and a cryopreserved control population raised contemporaneously with generation 5 selected rabbits. The animals were divergently selected for five generations for either a high $(\mathrm{H}$ line) or a low (L line) body weight, based on their BLUP breeding value. Heritability $\left(h^{2}\right)$ was 0.22 for 63 -d body weight $(N=4754)$. Growth performance and quantitative carcass traits in the $\mathrm{C}$ group were intermediate between the $\mathrm{H}$ and $\mathrm{L}$ lines $(N=390)$. Perirenal fat proportion $\left(h^{2}=0.64\right)$ and dressing out percentage $\left(h^{2}=0.55\right)$ ranked in the order $\mathrm{L}<\mathrm{H}=\mathrm{C}$ (from high to low). The weight and cross-sectional area of the Semitendinosus muscle, and the mean diameter of the constitutive myofibres were reduced in the $\mathrm{L}$ line only $(N=140)$. In the Longissimus muscle $(N=180)$, the ultimate $\mathrm{pH}\left(h^{2}=0.16\right)$ and the maximum shear force reached in the Warner-Braztler test $\left(h^{2}=0.57\right)$ were slightly modified by selection.
\end{abstract}

rabbit / growth / selection / genetic parameters / meat quality

\section{INTRODUCTION}

For many years, the aim of genetic selection in rabbit dam lines has been to increase the number of young born alive or still alive at weaning [34]. In sire lines, selection for high growth rate has been largely introduced, but genetic

*Corresponding author: larzul@dga.jouy.inra.fr

Present address: Station de génétique quantitative et appliquée, Inra, 78352 Jouy-en-Josas Cedex, France. 
selection on growth rate can modify the whole pattern of growth, the feed efficiency, and the tissue composition, thus affecting carcass and meat quality traits. The effects of postnatal weight gain on feed efficiency and carcass composition in rabbits have been studied [1, 8, 24, 26] using various breeds (dwarf, giant, commercial genotypes or native breeds) or lines selected for different criteria (e.g. growth $v s$. reproductive traits). Selection experiments have been recently conducted on increased average daily gain (ADG) $[6,22,35]$ or phenotypic mass at $70 \mathrm{~d}$ of age $[18,32]$, and genetic parameters associated with growth have been estimated. Few within breed studies have also examined the effects of selection for an increased growth rate on carcass fatness, but lower [27] or higher contents [31] in dissectible fat weights have been demonstrated in the selected animals. Negatively correlated phenotypic responses of selection for rapid growth rate on water holding capacity, myosin heavy chain type I percentage, or instrumental texture properties of the longissimus muscle have also been reported [31], but the consequences of selection for low growth rate on meat quality indicators are not known.

This study was aimed at determining the consequences of selection for a rapid or a low growth rate on carcass composition, muscle histological characteristics at slaughter, and indicators of meat quality traits (lipid content, $\mathrm{pH}$, colour, instrumental texture) in two divergent lines selected for five generations on body weight at a fixed age, and a control group from the same base population.

\section{MATERIALS AND METHODS}

\subsection{Origin of the animals}

Founder rabbits were obtained from a commercial heavy sire line widely used in terminal crosses in French rabbit production (Grimaud Frères, La Corbière, Roussay, France). They were introduced in 1996 on the INRA experimental farm (Langlade, Pompertuzat, France) after hysterectomy of fifteen does. The males were distributed into 11 groups, one per founding sire, and the females were randomly distributed among the 11 groups, avoiding fullsib mating. Two successive generations (G0 and G1) were needed to produce the starting breeder population made up of 11 groups, each with one sire and 7 dams. 


\subsection{Selection process}

The animals were weaned at $28 \mathrm{~d}$ of age and individually weighed at $63 \mathrm{~d}$ of age. The bucks and does were selected on their individual genetic value for live body weight at $63 \mathrm{~d}$ of age, estimated by BLUP applied on an animal model. The first step of selection took place in the G1 generation where bucks and does selected as breeders were chosen within-litter. The animals with the highest genetic values founded the high line $(\mathrm{H})$ and their full sibs with the lowest genetic values the low line $(\mathrm{L})$. The 11 original groups were represented in both lines. From the 2nd generation onwards, the animals were selected within group: each buck was replaced by its extreme son, and the does were chosen within sire progeny. The selected buck was kept in its group, and the does were distributed in the other groups to limit the increase of inbreeding. In the last generation, the inbreeding coefficient was $8.2 \%$ and $9.2 \%$ in the $\mathrm{H}$ and $\mathrm{L}$ lines, respectively.

Selected animals originated from two successive batches, and never belonged to the first parity progeny. In the case of divergent selection, the symmetrical evolution of the two lines cannot be verified, except if a control line is settled, for example with frozen embryos thawed at the end of the selection experiment. The advantages of such a control line are the almost complete absence of genetic drift and the limited cost of maintenance. This control line has previously been successfully used in selection experiments in rabbits [10, 26, 27]. To produce the control population, frozen [14] embryos from G0 were thawed and implemented in G4 females from both lines, in order to be contemporary of G5 rabbits from the selected lines. We obtained 44 bucks and 30 does out of 198 implanted embryos, and a G6 control group was obtained by mating 15 males and 21 females from this G5 control population.

\subsection{Animal management and measurements}

\section{Animals}

The total number of sires and dams was 204 and 595, respectively. A total of 5009 young rabbits were weighed at weaning (28 d). After weaning, growing rabbits were reared collectively in flat-deck cages (6 rabbits per cage). They had free access to a commercial pelleted diet (16.5\% protein, $2520 \mathrm{kcal} \cdot \mathrm{kg}^{-1} \mathrm{ME}$ ) and water. A total of $4754 \mathrm{rabbits}$ were weighed at $63 \mathrm{~d}$ of age. The average daily gain (ADG) was estimated between weaning and $63 \mathrm{~d}$ of age (g/days). 
At G3, G5 and G6, twenty pairs of full sibs were kept from the 2nd progeny in each line after weaning, and pair-caged. In one cage, two full sibs from the same litter were put together to have progeny from all families. The feed consumption per cage was measured from weaning to slaughter. Feed conversion (FC, g feed/g gain) was then calculated. At $63 \mathrm{~d}$ of age, without prior fasting, the rabbits were electrically stunned $(6 \mathrm{~s} 90 \mathrm{~V} 50 \mathrm{~Hz}$ direct current), and bled. Commercial dressing procedures were followed, including the removal of genital organs, the digestive tract, urinary bladder and skin.

\section{Carcass traits}

The hot carcasses [2], and skin were weighed immediately after slaughter. After $24 \mathrm{~h}$ chilling at $4{ }^{\circ} \mathrm{C}$ in a ventilated room, the cold carcasses [2] were weighed. The carcasses were then dissected according to the norms of the World Rabbit Science Association. The perirenal fat was removed from the carcass and weighed. Dressing out percentage (chilled carcass weight/live weight at slaughter), and perirenal fat percentage (weight/chilled carcass weight) were calculated. Carcass colour was assessed on the surface over the Biceps femoris (BF) muscle in G5 and G6. The colour measures L* (lightness), $\mathrm{a}^{*}$ (redness) and $\mathrm{b}^{*}$ (yellowness) were obtained with a Minolta chromameter (Minolta Camera, Osaka, Japan).

\section{Muscle collection}

The Semitendinosus muscle (ST) was excised in one-half of the carcasses within 20 min post-mortem (one per litter, $N=20$ from each selected line and the $\mathrm{C}$ group, for each generation) and weighed. The absence of any visible signs of contamination by inter-muscular fat depots was carefully checked in the muscle samples by visual examination. A slice (entire cross-section) was taken in the mid part of the ST muscle, cooled at $4{ }^{\circ} \mathrm{C}$ for $1 \mathrm{~h}$ after removal, and then frozen at $-20{ }^{\circ} \mathrm{C}$ for determination of the total muscle cross-sectional area. For the evaluation of myofibre characteristics, the samples were taken in the ST muscle at the same relative location (one sample in the oxidative deep part, one sample in the superficial glycolytic part). The samples were oriented according to the longitudinal fibre axis, restrained on flat sticks, and frozen in isopentane cooled by liquid nitrogen. For biochemical evaluation, the remaining left ST sample and the Longissimus lumborum (LL, 6-7th lumbar vertebra) were cut into small pieces and frozen in liquid nitrogen. All samples 
were stored at $-70{ }^{\circ} \mathrm{C}$ until analysis. After $48 \mathrm{~h}$ of carcass chilling, the LL (67th lumbar vertebra) and the ST muscles were carefully excised from the right carcass side for texture assessment.

\section{Histological traits}

The total muscle cross-section area $\left(\mathrm{mm}^{2}\right)$ was determined on frozen left ST muscles using a programmable planimeter (Kontron, AMO 3, France). Transverse serial sections (14 $\mu$ m-thick) cut with a cryostat (2800 Frigocut Reichert-Jung, Francheville, France), were stained with azorubin. The individual cross-sectional areas of myofibres were determined from three randomly selected fields in each part of the ST muscle, after inter-fibre network extraction, using a macro-program developed on an image analysis system (Optimas 6.5, Media Cybernetics, Silver-Spring, MD). The mean cross-sectional area $\left(\mathrm{CSA}, \mu \mathrm{m}^{2}\right)$ of myofibres was then calculated. Muscle fibre type composition was studied on $10 \mu \mathrm{m}$-thick transverse serial cross-sections stained for actomyosin ATPase activity, after pre-incubation at $\mathrm{pH} 4.35$ to identify types I (slow-twitch), IIA or IIB (fast-twitch) fibres. Percentages of type I, IIA and IIB fibres were determined from at least 1000 fibres into seven randomly selected fibre fasciculi, using a projection microscope (Reichert-Jung, Visopan, Wien, Austria).

\section{Muscle lipid content}

About $4 \mathrm{~g}$ of ST pieces were homogenised in methanol/chloroform (1:2, v/v), and intra-muscular lipids were extracted according to Folch et al. [9].

\section{Warner-Bratzler shear tests}

To assess the mechanical properties of the muscle, a Warner-Bratzler shear test was performed on raw ST or LL muscle samples using a universal test machine (synergie 200, MTS, MN, USA). Considering its small size, the whole ST muscle was used. Each LL muscle width was standardised at about $2.5 \mathrm{~cm}$ and two adjacent portions were obtained from each piece. Data are given as the mean of the measurements in the two pieces. Muscle sample was sheared at its centre using a Warner-Bratzler blade with a triangular hole drawn at $100 \mathrm{~mm} \cdot \mathrm{min}^{-1}$. The ST muscle was cut perpendicular to the muscle fibre orientation, while LL samples were positioned so that the superficial epimysial 
side was the sheared last [5]. The parameters from the force deformation curve were the maximal shear force (Fm, N), the energy at the maxima (Energy, mJ), and total energy (Energy tot, $\mathrm{mJ}$ ) defined as the area under the force displacement curve. Stress was calculated as follows: Fm/2x muscle area, expressed in $\mathrm{N} \cdot \mathrm{cm}^{-2}$ [36]. An estimation of the stiffness of the sample was assessed by calculating the $\mathrm{Fm} /$ displacement to $\mathrm{Fm}\left(\mathrm{N} \cdot \mathrm{mm}^{-1}\right.$ ratio).

\section{$p H$}

In the right portion of the carcasses chilled for $48 \mathrm{~h}$, the ultimate $\mathrm{pH}(\mathrm{pHu})$ was measured in situ in the LL (5th lumbar vertebra level), using a combined glass penetrating electrode (Ingold, Mettler Toledo, Switzerland) and a portable $\mathrm{pH}$ meter (Knick, Berlin, Germany). For the ST muscle, due to the heterogeneity between the red and white portions, the samples were first crushed in a solution of sodium iodo-acetate $(5 \mathrm{mM} ; 1: 9, \mathrm{w} / \mathrm{v})$, before $\mathrm{pHu}$ was measured using the apparatus described above.

\subsection{Statistical analyses}

Breeding values were estimated with the BLUP methodology applied to an individual model using the PEST package [13]. The model included sex, batch, and birth litter size (8 levels) as fixed effects, and permanent environment (dam) and animal as random effects. Heritability $\left(h^{2}\right)$ and permanent environment values $\left(p^{2}\right)$ were previously estimated in the original sire line $\left(h^{2}=0.18\right.$, $\left.p^{2}=0.18\right)$.

At the end of the experiment, the traits were analysed using the GLM procedure (SAS ${ }^{\circledR}$ Inst. Inc., Cary, NC, USA), in order to determine the effect of selection on the phenotypic evolution. For weight at $63 \mathrm{~d}$ of age, the fixed effects were litter size at weaning, generation, batch within generation, line within generation, and sex. For carcass and muscle traits, the model included the effects of litter size at weaning, generation (3 levels), line within generation (7 levels) and sex (2 levels). The least squares means for the line effect were compared separately within each generation (pdiff statement of the GLM procedure). Significance was set at $P<0.05$. Genetic parameters were estimated by the REML methodology for all traits with the effects mentioned above for breeding value estimation and with the common litter effect, using the VCE package [23] in bivariate analyses. For histological characteristics and lipid contents (only one rabbit per litter), the random litter effect was removed from the model. 
Table I. Selection intensity.

\begin{tabular}{ccccc}
\hline & \multicolumn{2}{c}{ Males } & \multicolumn{2}{c}{ Females } \\
\hline & Low line & High line & Low line & High line \\
\hline G1 & -1.06 & 1.12 & -0.69 & 0.59 \\
G2 & -0.62 & 0.57 & -0.41 & 0.33 \\
G3 & -0.67 & 0.74 & -0.65 & 0.49 \\
G4 & -1.08 & 1.21 & -0.56 & 0.40 \\
G5 & -0.47 & 0.92 & -0.55 & 0.47 \\
\hline
\end{tabular}

\section{RESULTS}

\subsection{Selection intensity}

The values of selection intensity for males and females are given in Table I. Mean selection intensity was similar in both lines, with a slightly higher selection intensity for females in the Low line and for males in the High line.

\subsection{Phenotypic evolutions}

The phenotypic differences between Low and High lines for body weight at 63 d (Fig. 1a), weaning weight (Fig. 2), and ADG (Fig. 3), were significant from G2 onwards. In G6, the difference between $\mathrm{L}$ and $\mathrm{H}$ lines was $450 \mathrm{~g}$ for 63-d body weight, corresponding to two standard deviations. For weaning weight and ADG, the difference between the two selected lines in the G6 generation was about one standard deviation $(68 \mathrm{~g}$ and $12 \mathrm{~g} / \mathrm{d}$ for weaning weight and $\mathrm{ADG}$, respectively). In this final generation, growth performance in the $\mathrm{C}$ group was intermediate between that in the $\mathrm{H}$ and $\mathrm{L}$ lines.

The FC ratio was lowered by $4 \%$ in the $\mathrm{H}$ line compared to the $\mathrm{L}$ line from G5 onwards (Tab. II), with the $\mathrm{C}$ group being intermediate between the two selected lines in G6.

The carcass merit of the L line was slightly lower, with a higher proportion of skin and a lower carcass yield. The differences between the $\mathrm{L}$ and $\mathrm{H}$ lines were significant from G5 onwards for the skin (+7\% on average) and perirenal fat proportion ( $+23 \%$ on average), and in G6 only for carcass yield (i.e., $-1.1 \%$ for dressing out percentage). Carcass merit was similar in the $\mathrm{C}$ group and the $\mathrm{H}$ line. Selection on growth did not significantly influence the exterior surface colour measurements.

In the ST muscle, the weight and the cross-sectional area were significantly lower in the $\mathrm{L}$ line compared to the $\mathrm{H}$ line, due to a hypotrophy of the constitutive myofibres (Tab. III). Differences between lines increased during the 


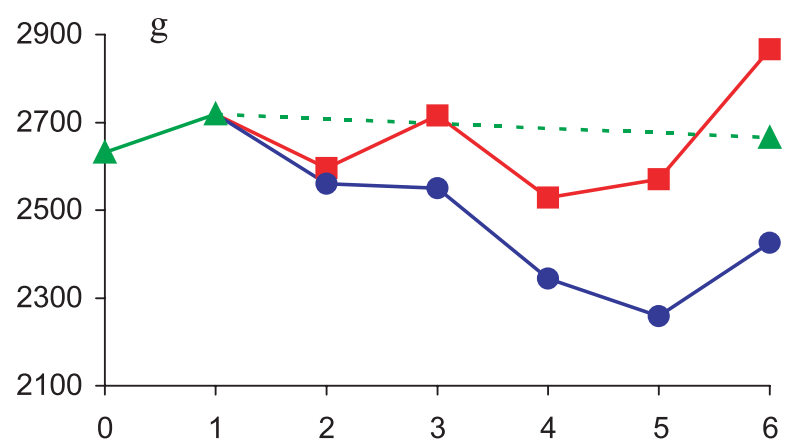

(a)

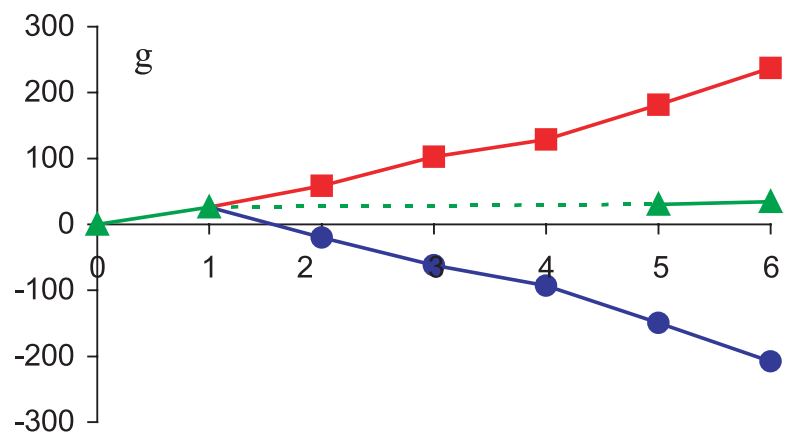

Generation

(b)

Figure 1. Phenotypic (a) and genetic (b) evolutions for body weight measured at 63 days of age, in rabbits divergently selected for a high (ם) or a low ( ) body weight at 63 days, and in the control population $(\boldsymbol{\Lambda}),\left(\sigma_{\mathrm{p}}=223 \mathrm{~g}\right)$.

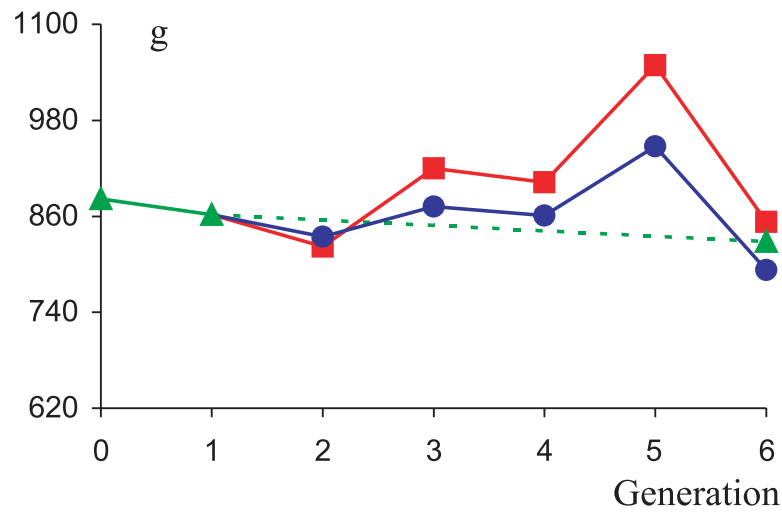

Figure 2. Phenotypic evolutions for the weaning weight in rabbits divergently selected for a high ( $\mathbf{\square})$ or a low $(\bullet)$ body weight at 63 days, and in the control population ( $\mathbf{\Delta})$, $\left(\sigma_{\mathrm{p}}=129 \mathrm{~g}\right)$. 


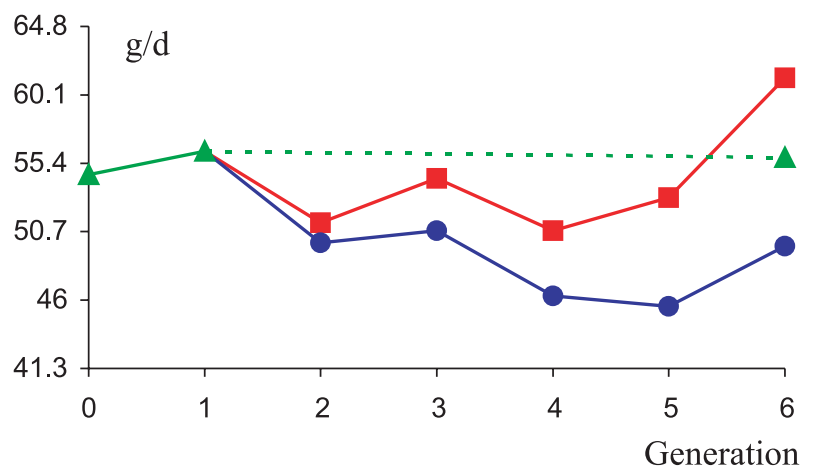

Figure 3. Phenotypic evolutions for the average daily gain in rabbits divergently selected for a high ( $)$ or a low ( ) body weight at 63 days, and in the control population $(\boldsymbol{\Lambda}),\left(\sigma_{\mathrm{p}}=4.89 \mathrm{~g} / \mathrm{d}\right)$.

Table II. Phenotypic evolution for feed conversion (FC) and for carcass traits at generations G3, G5 or G6 of selection for 63-day body weight ${ }^{1}$ in rabbits.

\begin{tabular}{|c|c|c|c|c|c|c|c|c|c|c|}
\hline \multirow[b]{2}{*}{ Traits } & \multirow[b]{2}{*}{ stde } & \multicolumn{2}{|c|}{ Effects } & \multicolumn{2}{|c|}{ G3 } & \multicolumn{2}{|c|}{ G5 } & \multicolumn{3}{|c|}{ G6 } \\
\hline & & Line & Sex & $\bar{L}$ & $\mathrm{H}$ & $\overline{\mathrm{L}}$ & $\mathrm{H}$ & $\overline{\mathrm{L}}$ & $\mathrm{C}$ & $\overline{\mathrm{H}}$ \\
\hline $\begin{array}{l}\text { Weight at } \\
\text { slaughter }(\mathrm{g})\end{array}$ & 201 & $* * *$ & $\mathrm{NS}$ & $2363^{\mathrm{a}}$ & $2678^{b}$ & $2426^{\mathrm{a}}$ & $2785^{\mathrm{b}}$ & $2423^{\mathrm{a}}$ & $2684^{b}$ & $2880^{c}$ \\
\hline $\begin{array}{l}\text { FC, g feed/g } \\
\text { gain }\end{array}$ & 0.18 & * & - & 3.15 & 3.19 & $3.12^{\mathrm{a}}$ & $2.99^{b}$ & $3.05^{\mathrm{a}}$ & $2.96^{\mathrm{ab}}$ & $2.90^{b}$ \\
\hline \multicolumn{11}{|l|}{ Percentage (\%) } \\
\hline Skin & 1.01 & **** & NS & $20.22^{\mathrm{a}}$ & $20.58^{\mathrm{a}}$ & $16.24^{b}$ & $15.62^{\mathrm{a}}$ & $19.12^{\mathrm{c}}$ & $18.23^{\mathrm{b}}$ & $17.55^{\mathrm{a}}$ \\
\hline Dressing out & 2.17 & $*$ & NS & 54.34 & 55.22 & 56.18 & 56.12 & $54.41^{\mathrm{a}}$ & $55.67^{\mathrm{b}}$ & $55.53^{\mathrm{b}}$ \\
\hline Perirenal fat & 0.42 & **** & $* * *$ & 1.68 & 1.70 & $1.51^{\mathrm{a}}$ & $1.82^{\mathrm{b}}$ & $1.62^{\mathrm{a}}$ & $1.92^{\mathrm{b}}$ & $2.04^{\mathrm{b}}$ \\
\hline \multicolumn{11}{|l|}{ Colour } \\
\hline $\mathrm{L}^{*}$ carcass & 2.15 & NS & * & - & - & 57.82 & 57.40 & 53.80 & 53.20 & 52.94 \\
\hline $\mathrm{a}^{*}$ carcass & 1.77 & NS & NS & - & - & 3.65 & 3.68 & 4.60 & 4.52 & 4.03 \\
\hline $\mathrm{b}^{*}$ carcass & 1.37 & NS & $* *$ & - & - & 3.04 & 2.94 & 4.39 & 4.23 & 3.78 \\
\hline
\end{tabular}

${ }^{1}$ Least square means $(N=40$ per line and per generation).

$* * * P \leq 0.001 ; * * P \leq 0.01 ; * P \leq 0.05$.

a,b,c Within each generation, least square means with different letters are significantly different $(P \leq 0.05)$.

selection (e.g., $-7 \%,-9 \%$ and $-16 \%$ for muscle total cross-sectional area at G3, G5, and G6, respectively). In contrast, the relative proportions of the different fibre types in the ST were not affected by selection. In G6, all histological traits measured in the $\mathrm{H}$ line were not significantly different from those in the C group. Instrumental texture assessed in ST and LL muscles was little affected by selection. The energy at a maximum shear force in G6 and the total energy 
Table III. Phenotypic evolution of histological, rheological, and biochemical traits for the Semitendinosus muscle at generations G3, G5 or G6 of selection for 63-day body weight in rabbits $(N=140)^{1,2}$.

\begin{tabular}{|c|c|c|c|c|c|c|c|c|c|c|}
\hline \multirow[b]{2}{*}{ Traits } & \multicolumn{3}{|c|}{ Effects } & \multicolumn{2}{|c|}{ G3 } & \multicolumn{2}{|c|}{ G5 } & \multicolumn{3}{|c|}{ G6 } \\
\hline & stde & Line & $\operatorname{sex}$ & $\mathrm{L}$ & $\mathrm{H}$ & $\mathrm{L}$ & $\mathrm{H}$ & $\mathrm{L}$ & $\mathrm{C}$ & $\mathrm{H}$ \\
\hline \multicolumn{11}{|l|}{ Histology } \\
\hline Muscle weight (g) & 0.75 & **** & NS & $7.03^{\mathrm{a}}$ & $7.67^{\mathrm{b}}$ & $7.06^{\mathrm{a}}$ & $8.05^{\mathrm{b}}$ & $7.08^{\mathrm{a}}$ & $8.04^{\mathrm{b}}$ & $8.46^{\mathrm{b}}$ \\
\hline Muscle CSA $\left(\mathrm{mm}^{2}\right)$ & 29 & $* * *$ & NS & $216^{\mathrm{a}}$ & $232^{\mathrm{b}}$ & $241^{\mathrm{a}}$ & $265^{\mathrm{b}}$ & $220^{\mathrm{a}}$ & $246^{\mathrm{b}}$ & $263^{b}$ \\
\hline Mean fibre CSA $\left(\mu \mathrm{m}^{2}\right)$ & 295 & $* * *$ & NS & $2737^{\mathrm{a}}$ & $2952^{b}$ & $2335^{\mathrm{a}}$ & $2641^{\mathrm{b}}$ & $2786^{\mathrm{a}}$ & $3374^{\mathrm{b}}$ & $3222^{\mathrm{b}}$ \\
\hline \multicolumn{11}{|c|}{ Fibre type proportion in the deep part $(\%)$} \\
\hline I & 5.23 & NS & NS & 19.84 & 20.12 & 16.58 & 16.86 & 17.41 & 17.95 & 17.03 \\
\hline IIA & 4.67 & NS & NS & 19.90 & 20.74 & 18.79 & 19.04 & 15.47 & 16.93 & 15.68 \\
\hline IIB & 6.89 & NS & NS & 60.27 & 59.14 & 64.64 & 64.10 & 67.12 & 65.12 & 67.29 \\
\hline
\end{tabular}

Fibre type proportion in the superficial part (\%)

$\begin{array}{lcccccccccc}\text { I } & 1.11 & \text { NS } & \text { NS } & 0.65 & 0.65 & 0.76 & 0.65 & 0.12 & 0.54 & 0.37 \\ \text { IIA } & 3.71 & \text { NS } & \text { NS } & 6.41 & 7.14 & 5.66 & 6.16 & 4.17 & 4.71 & 3.12 \\ \text { IIB } & 4.44 & \text { NS } & \text { NS } & 93.00 & 92.35 & 93.66 & 93.27 & 95.71 & 94.63 & 96.63\end{array}$

Texture

$\begin{array}{lllllllllll}\text { Maximum shear force } & 8.44 & * & \text { NS } & 28.4 & 33.8 & 41.1 & 45.1 & 36.7^{\mathrm{a}} & 44.4^{\mathrm{b}} & 38.6^{\mathrm{a}}\end{array}$ $(\mathrm{N})$

$\begin{array}{lllllllllll}\text { Energy at maximum } & 44 & * * & \text { NS } & 100 & 122 & 156 & 164 & 128^{\mathrm{a}} & 175^{\mathrm{b}} & 162^{\mathrm{b}}\end{array}$ shear force $(\mathrm{mJ})$

$\begin{array}{lllllllllll}\text { Total energy }(\mathrm{mJ}) & 88 & * * & \text { NS } & 345^{\mathrm{a}} & 433^{\mathrm{b}} & 534 & 558 & 404^{\mathrm{a}} & 494^{\mathrm{b}} & 449^{\mathrm{ab}}\end{array}$

$\begin{array}{llllllllllll}\text { Stress }\left(\mathrm{N} \cdot \mathrm{cm}^{-2}\right) & 1.74 & \text { NS } & \text { NS } & 6.94 & 9.14 & \text { nd } & \text { nd } & 8.71^{\mathrm{a}} & 7.48^{\mathrm{b}} & 7.64^{\mathrm{ab}}\end{array}$

$\begin{array}{lllllllllll}\text { Stiffness }\left(\mathrm{N} \cdot \mathrm{mm}^{-1}\right) & 18.3 & \text { NS } & \text { NS } & 45.9 & 53.9 & 57.1 & 60.5 & 63.0 & 67.5 & 57.7\end{array}$

Meat quality indicators

$\begin{array}{lllllllllll}\text { Ultimate } \mathrm{pH} & 0.09 & \mathrm{NS} & * & 5.98 & 5.92 & 6.11 & 6.07 & 6.13 & 6.13 & 6.09\end{array}$

\begin{tabular}{lllllllllll} 
Lipid content (\%) & 0.41 & NS & NS & 1.74 & 1.71 & 1.44 & 1.53 & $1.78^{\mathrm{a}}$ & $2.10^{\mathrm{b}}$ & $2.02^{\mathrm{ab}}$ \\
\hline
\end{tabular}

${ }^{1}$ Least square means $(N=20$ per line and per generation).

$* * * P \leq 0.001 ; * * P \leq 0.01 ; * P \leq 0.05$.

a,b,c Within each generation, least square means with different letters are significantly different $(P \leq 0.05)$.

${ }^{2}$ Abbreviation used: CSA: cross-sectional area.

needed to achieve rupture in G3 were $20 \%$ lower in the L line as compared to the $\mathrm{H}$ line for the ST muscle (Tab. III). In G6, muscles from the $\mathrm{C}$ group tended to be firmer (higher shear force, energy, and total energy) than those from the L line. In the same generation, however, the energy at the maximum shear force for the LL muscle (Tab. IV) was $14 \%$ higher in the L line than in the $\mathrm{H}$ line, whereas the $\mathrm{C}$ group tended to be firmer (higher shear force value and stiffness) than the $\mathrm{H}$ line. Only the $\mathrm{C}$ group tended to be firmer than the two selected lines within the last generation in both the ST (Tab. III) and LL 
Table IV. Phenotypic evolution of rheological and biochemical properties for the Longissimus lumborum muscle at generations G3, G5 or G6 of selection for 63-day body weight ${ }^{1}$ in rabbits $(N=180)$.

\begin{tabular}{|c|c|c|c|c|c|c|c|c|c|c|}
\hline \multirow[b]{2}{*}{ Traits } & \multirow{2}{*}{ stde } & \multicolumn{2}{|c|}{ Effects } & \multicolumn{2}{|c|}{ G3 } & \multicolumn{2}{|c|}{ G5 } & \multicolumn{3}{|c|}{ G6 } \\
\hline & & Line & Sex & $\mathrm{L}$ & $\mathrm{H}$ & $\mathrm{L}$ & $\mathrm{H}$ & $\mathrm{L}$ & $\mathrm{C}$ & $\mathrm{H}$ \\
\hline \multicolumn{11}{|l|}{ Texture } \\
\hline $\begin{array}{l}\text { Maximum shear } \\
\text { force }(\mathrm{N})\end{array}$ & 3.95 & $*$ & $* *$ & 22.4 & 24.8 & 35.3 & 35.1 & $33.9^{\mathrm{b}}$ & $34.5^{\mathrm{b}}$ & $31.2^{\mathrm{a}}$ \\
\hline $\begin{array}{l}\text { Energy at maximum } \\
\text { shear force }(\mathrm{mJ})\end{array}$ & 54 & NS & NS & 137 & 140 & 303 & 297 & $287^{\mathrm{a}}$ & $284^{\mathrm{ab}}$ & $251^{\mathrm{b}}$ \\
\hline Total energy (mJ) & 97 & NS & NS & $523^{\mathrm{a}}$ & $604^{\mathrm{b}}$ & 828 & 852 & 712 & 740 & 695 \\
\hline Stiffness $\left(\mathrm{N} \cdot \mathrm{mm}^{-1}\right)$ & 3.0 & $*$ & NS & $23.6^{\mathrm{a}}$ & $26.4^{\mathrm{b}}$ & 12.4 & 12.6 & $20.7^{\mathrm{ab}}$ & $21.2^{\mathrm{b}}$ & $19.2^{\mathrm{a}}$ \\
\hline \multicolumn{11}{|l|}{ Meat quality indicators } \\
\hline Ultimate $\mathrm{pH}$ & 0.08 & NS & $* *$ & 5.79 & 5.83 & 5.80 & 5.80 & 5.72 & 5.69 & 5.71 \\
\hline
\end{tabular}

muscle (Tab. IV). Significant differences between the H and L lines were found for the total energy needed to achieve rupture at G3 in the ST muscle $(\mathrm{L}<\mathrm{H})$, and for maximum shear force in the LL muscle at G6 $(\mathrm{L}>\mathrm{H})$.

The ultimate $\mathrm{pH}$ was not affected by selection in the two muscles, whereas lipid content was slightly decreased in the L line for the ST muscle in G6.

\subsection{Genetic parameters}

For the 63-d body weight, the realised heritability value calculated in both lines $\left(h^{2}=0.32\right)$ was very similar to the heritability estimated with REML methodology $\left(h^{2}=0.22\right.$, Tab. V). Litter effect and additive effect on 63-d body weight were similar. In contrast, the litter effect was larger than the additive genetic effect for weaning weight. Both heritability and litter effect values were moderate for ADG. High direct genetic correlations were found between 63-d body weight and ADG, or 63-d body weight and weaning weight. Medium to large heritabilities (0.43 to 0.64) were obtained for dressing proportions (Tab. V). Perirenal fat proportion was positively associated to 63 -d body weight, whereas the relative weight of the skin was negatively correlated with weight at slaughter. The genetic correlation between carcass yield 
Table V. Genetic parameters $( \pm \mathrm{SD})$ for growth, carcass and meat quality traits assessed in the Longissimus lumborum muscle $^{1}$ of rabbits.

\begin{tabular}{lccc}
\hline \multicolumn{1}{c}{ Traits $^{1}$} & $c^{2}$ & $h^{2}$ & $r_{g}$ \\
\hline Growth performance & & & \\
Weight at 63 days & $0.30 \pm 0.01$ & $0.22 \pm 0.02$ & \\
Weaning weight & $0.49 \pm 0.02$ & $0.13 \pm 0.02$ & $0.67 \pm 0.04$ \\
Average daily gain & $0.20 \pm 0.02$ & $0.29 \pm 0.03$ & $0.91 \pm 0.02$ \\
\hline Carcass traits & & & \\
Dressing proportions & $0.14 \pm 0.05$ & $0.43 \pm 0.09$ & $-0.39 \pm 0.10$ \\
$\quad$ Skin percentage & - & $0.55 \pm 0.10$ & $0.09 \pm 0.09$ \\
Dressing out & - & $0.64 \pm 0.11$ & $0.24 \pm 0.09$ \\
$\quad$ Perirenal far/chilled carcass & & & \\
Colour (external muscle surface) & $0.21 \pm 0.09$ & $0.01 \pm 0.01$ & $n e$ \\
L* & $0.04 \pm 0.06$ & $0.01 \pm 0.01$ & $n e$ \\
a* & $0.01 \pm 0.09$ & $0.01 \pm 0.01$ & $n e$ \\
$\quad \mathrm{~b}^{*}$ & & & \\
\hline Meat quality traits (Longissimus lumborum) & & & \\
pH & $0.03 \pm 0.06$ & $0.16 \pm 0.09$ & $0.02 \pm 0.11$ \\
Maximum shear force & - & $0.57 \pm 0.02$ & $0.02 \pm 0.10$ \\
Energy at maximum & - & $0.09 \pm 0.12$ & $-0.18 \pm 0.26$ \\
\hline
\end{tabular}

${ }^{1} c^{2}=$ common environment; $h^{2}=$ heritability; $r_{g}=$ genetic correlation with 63 -day body weight; ne $=$ non-estimable.

and 63-d body weight was not significant. CIELAB colour measurements had null heritability values.

Shear force and energy applied at a maximum shear force in the WarnerBratzler test displayed moderate heritability in the LL muscle (Tab. V). The ultimate $\mathrm{pH}$ had a low heritability value $\left(h^{2}=0.16\right)$, and a null genetic correlation with $63-\mathrm{d}$ body weight. The heritability values calculated for other muscle traits had very high standard errors and are not shown.

\subsection{Genetic evolutions}

The genetic evolutions were in accordance with the phenotypic evolutions for 63-d body weight. The evolutions were very similar in low and high lines (Fig. 1b). The control line was in between the two selected lines, and had the same genetic level as the founder population. 


\section{DISCUSSION}

\subsection{Symmetrical and asymmetrical responses for selection on body weight at a fixed age}

As a consequence of selection, the animals of the high or low lines were heavier or lighter, respectively, than the control animals at weaning and at 63 days of age, in agreement with the observations by Piles and Blasco [26] that rabbits selected for increased growth rate are heavier than control animals throughout the entire growth curve. Successful selection in rabbits was previously shown for ADG $[4,22,35]$ and body weight at market age $[18,34]$. However, a higher genetic progress for body weights and ADG was obtained in the present work, mainly because of the efficiency of selection on BLUP breeding values in comparison with selection on phenotypic values. For instance, post-weaning ADG was currently increased by nearly $1 \mathrm{~g} / \mathrm{d}$ per generation of selection on 63-d body weight, versus $0.83 \mathrm{~g} / \mathrm{d}$ for Rochambeau et al. [34] and $0.45 \mathrm{~g} / \mathrm{d}$ for Piles and Blasco [26] per generation by direct selection on postweaning ADG breeding values. In agreement with previous studies on rabbits selected for ADG $[8,22]$, the lowest feed conversion ratio was observed in the rapid-growing animals, since the genetic correlation between ADG and market weight was high $\left(r_{g}=0.82\right.$ to 0.91 , current study, [22]).

In divergent selection experiments on growth, asymmetrical responses for growth traits between upward and downward lines are generally observed in rabbits [21] and other species [37]. The symmetrical responses to selection for growth performance observed in the present study may partially arise from the fact that selection was carried out on breeding values. However, asymmetrical responses to selection were obtained for carcass conformation, with responses in the low line only.

\subsection{Genetic parameters for growth performance and qualitative traits}

The heritability value estimated for 63-d body weight was similar to that previously estimated for commercial slaughter weight in rabbits $\left(h^{2}=0.15\right.$ to $0.36,[4,11,12,35])$. Similarly, the estimated heritability value for ADG between 4 and 9 wk was very similar to the value reported by Piles et al. [28], but was slightly higher than that reported in rabbits selected on 70-d mass weight $(0.17,[18])$ or for 4 to $10 \mathrm{wk} A D G(0.23,[34])$. The high positive genetic correlation between 63-d body weight and 4 to $9 \mathrm{wk}$ ADG, was close to that reported between 70-d body weight and 3-4 to $10 \mathrm{wk}$ ADG $\left(r_{g}=0.91\right.$ to $0.98,[18,40])$. Indeed, a moderate correlated response $\left(r_{g}=0.50\right.$ to 0.64$)$ for 
weaning weight in rabbits selected on market body weight has been reported previously $[18,22])$. Interestingly, the common (litter) effect was markedly larger than the direct additive effect for weaning weight, in accordance with Lukefahr et al. [18]. In contrast to this latter study, we obtained similar estimates for the litter effect and direct effect on 63-d body weight and on ADG.

The genetic parameters associated with carcass merit and meat quality have been little estimated in rabbits. The heritability $\left(h^{2}=0.55\right)$ currently estimated for dressing out percentage was similar to that reported for rabbits selected on 70-d body mass $\left(h^{2}=0.37,[18]\right)$ and higher than the low heritability value $\left(h^{2}=0.17\right)$ reported by $\mathrm{Su}$ et al. [39]. In pigs, the heritability for carcass yield is considered as moderate [38].

Interestingly, the Warner-Brazler shear force had a moderate heritability, in agreement with other studies on pigs [38].

\subsection{Phenotypic responses for qualitative traits}

As previously reported for rabbits selected on ADG [40] or body mass [27], the present results suggest that rabbit dressing out percentage was slightly affected by selection for growth rate. Phenotypically, both a decrease [27, 29] and an increase [31] in carcass fatness have been reported in rabbits selected for a high growth rate and in two lines of rabbits selected for growth rate compared to a line selected on litter size [12]. In mice, most studies indicate that at a fixed age, lines selected for high body weight tend to be fatter [19]. The animals selected for a high growth rate are generally approximately as mature as unselected animals from the same origin at the same age [3], which could explain the lack of variation in carcass fat content currently observed between the high line and controls. The present study rather suggested that only selection for a low growth rate results in a decreased perirenal fat proportion and a slightly lower lipid content in Semitendinosus muscle. Interestingly, both carcass fatness and feed efficiency were depressed in the L line only, from G5 onwards.

No effect of selection was found in the ultimate $\mathrm{pH}$ values of both muscles at a fixed slaughter age and no evidence of phenotypic differences in ultimate $\mathrm{pH}$ of the Longissimus muscle between fast growing and control animals was found in previous works $[27,31]$. In contrast to the present results, negative genetic correlations have been reported in rabbits between ultimate $\mathrm{pH}$ and growth rate $(-0.05$ to $-0.55,[16])$. It has also been suggested that continual selection of mammals for rapid growth accompanied by a higher development of the musculature should entail fibre type conversion, leading to a 
more pronounced glycolytic character and a lower ultimate $\mathrm{pH}$ in fast-growing animals [1]. However, the muscle fibre type proportion was not affected by selection on body weight, in agreement with studies on divergently growthselected chickens or mice at a fixed age $[32,33]$. The assumption that oxidative metabolism is related negatively to muscularity (proportion of muscle weight to carcass weight) and positively to the maturity degree of the animals at slaughter (proportion of body weight to adult weight) might help explain these differences.

The present results did not confirm the statement that the meat of growthselected rabbits may show higher firmness [30,31], but the Warner-Braztler shear test was performed either on raw (current study) or on cooked meat [30,31]. Finally, for Semitendinosus and Longissimus lumborum texture traits, opposite responses to selection were currently evidenced, probably as a consequence of the methodology applied during the texture test (entire muscle or standardised squares, respectively). Overall, the present work suggests that the structure of the muscle at slaughter did not markedly diverge between the growth selected lines. Previous sensory analysis also showed similar hardness in a growth-selected group and a control group [15].

No previous results are available on the influence of selection for growth on muscle fibre architecture in rabbits. The significant hypotrophy of crosssectional areas of myofibres in the low line was in agreement with observations on chickens [33] and cattle [17]. It was generally accompanied by an increase in total fibre number [7,33]. Fibre number is fixed shortly after birth in rabbits, thereafter the fibre enlargement is due to additional DNA from satellite cell proliferation and differentiation [25]. Selection on post-weaning growth rate appears to alter the amount of DNA synthesised in the muscle, at least in mice [20], which might explain the difference in fibre cross-sectional areas observed between $\mathrm{L}$ and $\mathrm{H}$ rabbit lines.

\section{CONCLUSION}

Selection for growth rate in rabbits is efficient. After five generations of selection, an accurate rabbit model was produced in order to estimate the effects of increased or decreased body weight on carcass composition and muscle characteristics at a fixed age. Although quantitative weights have been increased by selection in the rapid growing line, the qualitative traits did not differ significantly between highly selected animals and the control population. 


\section{ACKNOWLEDGEMENTS}

This experiment was supported by Grimaud Frères (La Corbière, Roussay, France). Thanks are extended to the entire staff of the rabbit experimental unit in Langlade (SELAP). We are indebted to T. Joly, J. Falières, M. TheauClément and G. Bolet for the constitution of the cryopreserved population. Appreciable technical assistance was provided by F. Pontrucher, S. Morlière, L. Cauquil, B. Darche and B. Peña-Arnaud.

\section{REFERENCES}

[1] Aberle E.D., Doolittle D.P., Skeletal muscle cellularity in mice selected for large body size and in controls, Growth 40 (1976) 133-145.

[2] Blasco A., Ouhayoun J., Harmonization of criteria and terminology in rabbit meat research. Revised proposal, World Rabbit Sci. 4 (1996) 93-99.

[3] Blasco A., Piles M., Varona L., A Bayesian analysis of the effect of selection for growth rate on growth curves in rabbits, Genet. Sel. Evol. 35 (2003) 21-41.

[4] Cantier J., Vezinhet A., Rouvier R., Dauzier L., Allométrie de croissance chez le lapin, Ann. Biol. Anim. Bioch. Biophys. 9 (1969) 5-39.

[5] Combes S., Auvergne A., Lebas F., Effect of cooking temperature on WarnerBratzler tenderness measurement in rabbit meat, in: Proceedings of the 7th World Rabbit Congress, Valencia, 4-7 July 2000, Spain, Vol. A, pp. 573-578.

[6] Estany J., Camacho J., Baselga M., Blasco A., Selection response of growth rate in rabbit for meat production, Genet. Sel. Evol. 24 (1992) 527-537.

[7] Ezekwe M.O., Martin R.J., Cellular characteristics of skeletal muscle in selected strains of pigs and mice and the unselected controls, Growth 39 (1975) 95-106.

[8] Feki S., Baselga M., Blas E., Cervera C., Gómez E.A., Comparison of growth and feed efficiency among rabbit lines selected for different objectives, Livest. Prod. Sci. 45 (1996) 87-92.

[9] Folch J., Lees M., Stanley G.H.S., A simple method for the isolation and purification of total lipids from animal tissues, J. Biol. Chem. 226 (1957) 497-509.

[10] García M.L., Baselga M., Estimation of genetic response to selection in litter size of rabbit using a cryopreserved control population, Livest. Prod. Sci. 74 (2002) $45-53$.

[11] Garreau H., Szendro Zs., Larzul C., Rochambeau H. de, Genetic parameters and genetic trends of growth and litter size traits in the White Pannon breed, in: Proceedings of the 7th World Rabbit Congress, Valencia, 4-7 July 2000, Spain, Vol. A, pp. 403-408.

[12] Gomez E.A., Rafel O., Ramon J., Genetic relationships between growth and litter size traits at first parity in a specialized dam line, in: Proc. 6th World Cong. Genet. Appl. Livest. Prod., 11-16 January 1998, Vol. 25, University of New England, Armidale, pp. 552-555.

[13] Groeneveld E., Kovac M., A generalized computing procedure for setting up and solving mixed linear models, J. Dairy Sci. 73 (1990) 513-531. 
[14] Joly T., Renard J.P., Établissement d'une cryobanque de gamètes et d'embryons : un nouvel outil pour la sélection et la conservation des populations de lapins, in: Proceedings of the $6^{\text {es }}$ Journées de la Recherche Cunicole en France, 6-7 December 1994, Vol. 1, La Rochelle, pp. 225-233.

[15] Hernandez P., Guerrero L., Ramirez J., Ariño B., Blasco A., Effecto de la seleccion por velocidad de crecimiento sobre la calidad sensorial de la carne de conejo, Informacion Técnica Economica Agraria 24 (2003) 256-258.

[16] Hulot F., Ouhayoun J., Muscular pH and related traits in rabbits: a review, World Rabbit Sci. 7 (1999) 15-36.

[17] Johnston D.M., Stewart D.F., Moddy W.G., Boling J., Kemp J.D., Effects of breed muscle fiber types, J. Anim. Sci 40 (1975) 613-620.

[18] Lukefahr S.D., Odi H.B., Atakora J.K.A., Mass selection for 70-day body weight in rabbits, J. Anim. Sci. 74 (1996) 1481-1489.

[19] Malik R.C., Genetic and physiological aspects of growth, body composition and feed efficiency in mice: a review, J. Anim. Sci. 58 (1984) 577-590.

[20] Martin R., White J., Muscle and adipose cell development in mice selected for postweaning growth rate, Growth 43 (1979) 67-173.

[21] Mgheni M., Christensen K., Selection experiment on growth and litter size in rabbits. II. Two-way selection response for body weight at 112 days, Acta Agric. Scand. 35 (1985) 278-286.

[22] Moura A.S.A.M.T., Kaps M., Vogt D.W., Lamberson W.R., Two-way selection for daily gain and feed conversion in a composite rabbit population, J. Anim. Sci. 75 (1997) 2344-2349.

[23] Neumaier A., Groeneveld E., Restricted maximum likelihood estimation of covariances in sparse linear models, Genet. Sel. Evol. 30 (1998) 3-26.

[24] Ouhayoun J., Rouvier R., Poujardieu B., Genetic relations between ponderal growth performances and muscular tissue metabolism in rabbits, in: Proc. 1st World Cong. Genet. Appl. Livest. Prod., 7-11 October 1974, Madrid, pp. 521-528.

[25] Picard B., Lefaucheur L., Berri C., Duclos M.J., Muscle fibre ontogenesis in farm animal species, Reprod. Nutr. Dev. Anim. 42 (2002) 415-431.

[26] Piles M., Blasco A., Response to selection for growth rate in rabbits estimated by using a control cryopreserved population, World Rabbit Sci. 11 (2003) 53-62.

[27] Piles M., Blasco A., Pla M., The effect of selection for growth rate on carcass composition and meat characteristics of rabbits, Meat Sci. 54 (2000) 347-355.

[28] Piles M., Gomez E.A., Rafel O., Ramon J., Blasco A., Elliptic selection experiment for the estimation of genetic parameters on the growth rate and feed conversion ratio in rabbits, J. Anim. Sci. 82 (2004) 654-660.

[29] Pla M., Hernandez P., Blasco A., Carcass composition and meat characteristics of two rabbit breeds of different degrees of maturity, Meat Sci. 44 (1996) 85-92.

[30] Pla M., Guerrero L., Guardia D., Oliver M.A., Blasco A., Carcass characteristics and meat quality of rabbit lines selected for different objectives: I. Between lines comparison, Livest. Prod. Sci. 554 (1998) 115-123.

[31] Ramirez J.A., Oliver M.A., Pla M., Guerrero L., Ariño B., Blasco A., Pascual M., Gil M., Effect of selection for growth rate on biochemical, quality and texture characteristics of meat from rabbit, Meat Sci. 67 (2004) 617-624. 
[32] Rehfeldt C., Bünger L., Effects of long-term selection of laboratory mice on parameters of muscle growth and muscle structure, J. Anim. Breed. Genet. 33 (1990) 507-516.

[33] Rémignon H., Gardahaut M.F., Marche G., Ricard F.H., Selection for rapid growth increases the number and the size of muscle fibres without changing their typing in chickens, J. Muscle Res. Cell Motil. 16 (1995) 95-102.

[34] Rochambeau H. de, Fuente L.F. de la, Rouvier R., Ouhayoun J., Sélection sur la vitesse de croissance post-sevrage chez le lapin, Genet. Sel. Evol. 21 (1989) $527-546$.

[35] Rochambeau H. de, Retailleau B., Poivey J.P., Allain D., Sélection pour le poids à 70 jours chez le lapin, in: Proceedings of the $6^{\mathrm{es}}$ Journées de la Recherche Cunicole en France, 6-7 December 1994, Vol. 1, La Rochelle, pp. 235-240.

[36] Salé P., Evolution of muscle mechanical properties during maturation, in: Proceedings of the 17th European Meeting of Meat Research Workers, Bristol, 1971, Vol. 1, pp. 35-44.

[37] Sellier P., Genetically caused retarded growth in animals, Domestic Anim. Endocrinol. 19 (2000) 105-119.

[38] Sellier P., Genetics of meat and Carcass traits, in: Rothschild M.F., Ruvinski A. (Eds.), The genetics of the pig, Cab international, 1998, pp. 463-510.

[39] Su G., Kjaer J.B., Brenøe U.T., Sørensen P., Estimates of genetic parameters in Danish white rabbits using an animal model: I. Growth and carcass traits, World Rabbit Sci. 7 (1999) 59-64.

[40] Szendro Zs., Kustos K., Richter J., Estimation of heritability of live weights and weight gains in different ages of rabbits, in: Proceeding of the 4th World Rabbit Congress, 1988, Vol. 2, p. 284.

To access this journal online: www.edpsciences.org 